\title{
THE ACCEPTANCE FACTOR TOWARDS SUSTAINABLE FARMING TECHNOLOGY AMONG FARMERS
}

\author{
Juan Rizal Sa'ari1,2*, Juhaini Jabar'1, Md. Nor. Hayati Tahir'1, Fadhlur Rahim Azmi1 , Noraznira Abd \\ Razak $^{2}$, Melissa Wee 2 , Najihah Hanisah Marmaya², Faizah Mashahadi ${ }^{2}$ \\ 1Fakulti Pengurusan Teknologi dan Teknousahawan, Universiti Teknikal Malaysia Melaka, Hang Tuah \\ Jaya, 76100 Durian Tunggal, Melaka, Malaysia \\ ${ }^{2}$ Faculty of Business and Management, Universiti Teknologi MARA, Melaka Branch, Jalan Lendu, \\ 78000 Melaka, Malaysia \\ *juanrizal@melaka.uitm.edu.my
}

\begin{abstract}
Sustainable farming is as yet another way or strategy for cultivating in the business. The farmers here in Malaysia are as yet not comfortable with the practical method for cultivating. A portion of the farmers have executed such technology however neglected to make progress since they are absence of information and ability. For the most recent decades, the impact of innovation has driven the progressions in the greater part of the association. These days business culture is moving towards green business activities. There are developing consideration of business visionaries perceive that doing supportability or anything identified with green is useful for their business and furthermore to the earth. In particular, the goal of this investigation is to distinguish the elements that urge farmers to acknowledge Sustainable farming technology. Factors for foreseeing the acknowledgment of Sustainable Farming Technology is relied upon to be delivered toward the end of the study. The study is additionally meant to increase the value of the current literature in the investigating of farmers utilizing sustainable farming technology in their business and towards the national plan.
\end{abstract}

Keywords: Sustainable Farming Technology, Technology Acceptance, Farmers, Green Technology, Organic Farming

\section{INTRODUCTION}

Sustainable farming technology has caught the enthusiasm of creating nations and the numbers are developing since it depends on the accessibility of natural and human resources (Bhatta et al., 2009). Sustainable farming technology or environmental related technology can likewise be called Green or sustainable initiative is a preference method that can reduce petroleum or fuel consumption, landfills and mechanical wastages that may deleterious to human, animal and plant wellbeing. Confiding in innovation or trusting that an innovation has alluring characteristics appears to be sensible on the grounds that we discuss confiding in non-human entitles in ordinary talk (Lankton et al., 2015). Natural related innovation has turned out to be more vital in impacting and forming authoritative system and upgrades financial returns (Kathiresan, 2007). Additionally such wastages are detrimental to the earth through climate changes (Abu Bakar et al., 2011). Green advancements incorporate of a sustainable power sources, squander administration, remediation of ecological contaminations, sewage treatment, reusing and water cleansing which enhances farming frameworks. Olson (2008) expressed that the proposed "green" methodology for big business level is to help undertakings in basic leadership that will positively affect the earth. The growth of sustainable farming technology which is also known as sustainable agricultural practices is likely to enhance the supportability of horticultural frameworks (Tey et al., 2012). There are issues arising in regards to the sustenance of wellbeing and natural amicability which is now imperative. In concern to the issues, the world is now moving towards a greener environment by creating a safe and harmless advancement for the ecosystem way (Mohamed \& Shamsudin, 2011).

Sustainable farming technology is yet another method for cultivating in the agricultural industry and is highly associated with the input supply and the practices conducted by the farmers. It utilizes natural input and non-chemical materials that can be assembled from homesteads and family units 
(Pattanapant \& Shivakoti, 2009). Numerous nearby famers are not familiar with this sort of sustainable farming technique as it is rather peculiar and new to the industry. Nevertheless, sustainable farming technology gives a great impact towards our farmers. It also have a lower environmental impacts compared with conventional farming technology (Tuomisto et al., 2012). A portion of farmers have executed such innovation however neglected to make progress since they are absence of information and aptitude (Hu et al., 2012).

\section{LITERATURE REVIEW}

\section{Sustainable Farming Technology}

One of the cases in sustainable farming technology is organic farming technology. Organic farming technology is characterized as utilizing customary strategy and such farming technology as in the meantime actualizing modern day technology to upgrade diversity into farming method (Bhatta et al., 2009). It is an additionally option to conventional agriculture that can support agricultural improvement, may dodge negative impact to the natural cause by human doings, food security and can upgrade the monetary performance for organization (Tuomisto et al., 2012; Hu et al., 2012; Oleskowicz-Popiel et al., 2012; Maffei et al., 2013; Patil et al., 2012; De Ponti et al., 2012; Santos et al., 2012). A production mechanism that manages the purity of soil, biological systems and human being can characterize as an initiative to organic farming technology. It combines the traditional, technology innovation and the sciences to promote a balance ecological atmosphere.

Malaysian has poor awareness on the sustainable farming technology (Tey et al., 2012). Tey et al. (2012) recommended from their previous study, indicating that Malaysian vegetable sector has encountered a low adoption rate of sustainable farming practices and suggested that only few farmers implemented it. Advance change on organic farming technology is vital later on (Hu et al., 2012). In this report we can decide the acknowledgment of sustainable farming technology among farmers.

\section{Performance Expectancy}

Performance Expectancy is described as how much a person trusts and utilizes a system which will help him or her to make gains in their occupation (Venkatesh et al., 2003). This factor derived from the perceived usefulness factor as demonstrate in The Acceptance Model. People believe that a higher perceived usefulness, will diminish their uncertainties in doing their jobs and eventually will increase their job performance (Venkatesh et al., 2003; Davis, 1989; Amoako-Gyampah, 2007). A study by Kumar et al. (2013) mentioned that performance expectancy have a positive effect to the end user to accept using a system. Thus, the following hypothesis is proposed.

H1: Performance Expectancy positively effect on the acceptance of Sustainable Farming Technology among Farmers in Malaysia.

\section{Effort Expectancy}

Effort Expectancy is characterized as the level of simplicity connects with the utilization of a system. This factor resulted from the perceived ease of use factor proposed in The Acceptance Model. It was discovered that an application saw by individuals which is simpler to utilize is more expected that would be sufficient to use (Davis, 1989). Additionally, Davis (1989) also mentioned that the behaviour in using a system are more significant at the early stages to overcome certain difficulties that need to be solve and will later the concerns on the instrumentality will took over. Effort expectancy have a significant parts in foreseeing the goal to accepting using a system and fundamentally one of the factor that explain the behavioural intention to use a system as mentioned by Carter et al. (2011). Furthermore, effort expectancy altogether has highly associated with the behavioural intention and has direct effect to accept using a technology (Venkatesh et al., 2003). Thus, the following hypothesis is proposed.

H2: Effort Expectancy positively effect on the acceptance of Sustainable Farming Technology among Farmers in Malaysia.

\section{Social Influence}

Social influence was considered as a part of social norm on the improvement and stimulation of an individual norm (Klöckner \& Ohms, 2009). Social influence is how much a person feels that it is essential for others to believe that they also need to use the same system as they are (Venkatesh et al., 
2003). It is believed that farmers who have the accessibility of a major relative can be affected in tolerating to accept sustainable farming technology (Garcia-Yi, 2014). Thus, the following hypothesis is proposed.

H3: Social Influence positively effect on the acceptance of Sustainable Farming Technology among Farmers in Malaysia.

\section{Facilitating Condition}

Facilitating conditions is characterized in this study as how much a farmers believe that training in the oganization exists to help the acceptance of sustainable farming technology innovation (Venkatesh \& Davis, 2000; Venkatesh et al., 2003). With respect to training, it is characterized as a learning knowledge process enhance the ability of a person to perform doing a job they acquired. The term training frequently concentrates on specialized knowledge, aptitudes and capacities to finish current undertakings or as an effort initiated by the organization to cultivate learning culture among their employees (Treven, 2003). The concerns about risk, market acceptance and monetary gain will be addressed adequately before the acceptance of a technology (Cook \& Fairweather, 2003). In addition the market and the consumer will remain the main drivers in accepting a technology (Abdullah et al., 2012). Thus, the following hypothesis is proposed.

H4: Facilitating Conditions positively effect on the acceptance of Sustainable Farming among Farmers in Malaysia.

\section{Access to Finance}

Access to financing is characterized in this study is to which farmers believe that when they have better and prepared monetary capital and fund, they are more inclined to tolerate accepting a new technology (Abdullah et al., 2012; Noltze et al., 2012). Farmer will most likely be unable to accept a technology in light of constrained assets, for example, absence of capital (De Graaff et al., 2008). A substantial investment need to be acquired by the farmers in order to accept a technology and it could not be done if the farmers did not have access to financial resources (Kersting \& Wollni, 2012). It has been proven by a study by Durkin et al. (2013) stated that when the closely acquainted relationship built a farmers with a financial institution, it is well assured that they will be given the financial support with regards with other fulfilled requirements by the financial institution. It is particularly suggested by Iacovou et al. (1995) with substantial financial resources, incentives and subsidization will lead to rapid technology acceptance in an organization. Access to financing is also a prerequisite for a Small and Medium Enterprise to fund operations and capital investment indirectly ensure growth for the organization (10th Malaysia Plan, 2010). Facilitating conditions is characterized in this study as how much a farmers believe that training in the organization exists to help the acceptance of sustainable farming technology innovation (Venkatesh \& Davis, 2000; Venkatesh et al., 2003). Thus, the following hypothesis is proposed.

H5: Access to Finance positively effect on the acceptance of Sustainable Farming among Farmers in Malaysia.

\section{METHODOLOGY}

\section{Population and Sample Selection}

Target population in this study focused on the farmers that may implement sustainable farming technology in their farm. Farmers registered under Farmers Organization Authority Malaysia (FOAM), a central agency for farmers commissioned by the Malaysian Government to formulate policies and coordinate programs are among the agencies relevant that were selected as the population. A total of 195 respondents participated in this study. The selection of sample is based on purposive sampling method or also known as judgemental sampling method. According to Sekaran and Bougie (2016), purposive sampling method is a non-probability sampling design refers to the collection of information or data from members of the population who are most advantageously placed or in the best position and knowledge to provide the information required. Purposive sample consist of a group of experts with the knowledge about a particular area or issue, which in this research is refers on farmers (Kumar et al., 2013). The farmers had to fulfil two criteria to be selected that is the selected farmers must be registered in the list from the Farmers Organization Authority Malaysia (FOAM), and the questionnaire have to be fill in by the farmers or farm owners. One of the cases in sustainable farming technology is organic farming technology. 


\section{Research Instrument, Data Collection and Data Analysis}

In data collection, this study entailed distribution of self-administered closed-ended questionnaire survey adapted from previous researchers. Since the list of farmers from the Farmers Organization Authority (FOAM) are private and confidential, FOAM agree to distribute the questionnaire on behalf of the researcher. As mentioned by Sekaran and Bougie (2016) that closed questions help respondents to make quick decisions to choose among the several alternatives before them. Furthermore, they help the researcher to easily code the information for subsequent analysis. As such, this study utilizes the closed questions in the survey. In addition, as this paper is a study of perceptions on how strongly the respondents agree or disagree with certain statements, Likert scale is the best to be used (Sekaran \& Bougie, 2016) and (Kumar et al., 2013). The researchers have decided to follow Kumar et al. (2013), Sekaran and Bougie (2016) by using five-point Likert scale in the study because it is able to stimulate responses with regard to the object, event or person studied. It is also allow the respondent to be neutral on the question given. Statistical Package for Social Sciences (SPSS) version 20 was used to compute the descriptive statistics (frequencies, percentages, median) for the respondents' demographic profile while SmartPLS was used for partial least squares analysis of the study's measurement model (Hair et al., 2010; Ramayah et al., 2013).

\section{RESULTS AND DISCUSSION}

This section showed the result of data analyzed using the method as explained in previous section. Results of the analysis illustrated the list of findings on relationship of farmers' determinants towards acceptance of sustainable farming technology among farmers. Respondents were sampled as they were directly involved in agricultural industries all over Malaysia that focus on green technology. Their feedback on each of questions recorded in questionnaire booklet. They were also engaged in respond to their views on technology acceptance. Thus, their data to the issues raised in the given questionnaires have credibility for analysis. Out of 300 questionnaires distributed, 195 respondents replied the questionnaires which response rate is at $65 \%$. From total replied, all returned in a complete feedback. Questionnaires were distributed only to person who deals directly with farming matters.

\section{Demographic Profile of Companies}

There are quite of numbers of farmers responded their acceptance of sustainable farming technology in Malaysia. Most of the companies were from Negeri Sembilan (39\%), followed by Melaka (12.3\%), Pahang (11.8\%), Johor (10.3\%), Perlis (10.3\%), Selangor (7.2\%), Kelantan (2.6\%), Kedah (2.1\%), Perak (1.5\%), Sabah (1.5\%), Wilayah Persekutuan (1.0\%) and Terengganu (0.5\%). Respondents taken from companies operated various types of agriculture products. This led by $50.3 \%$ of respondents from companies that produced vegetable products, followed by fruits $(16.9 \%)$, agro-based industries $(16.9 \%)$, livestocks $(6.2 \%)$, others agriculture products $(4.6 \%)$, agro support services $(3.1 \%)$ and aquaculture $(2.1 \%)$.

\section{Assessment of the Measurement Model}

Convergent validity were tested first that is the degree to which multiple items measuring the same concept are in arrangement. The used of factor loadings, composite reliability and average variance extracted to access convergence validity (Hair et al., 2014). The indicator loadings, composite reliability (CR) and average variance extracted (AVE) of the reflective construct are shown in Table 1. All the loadings which exceed the recommended value of 0.708 (Fornell \& Larcker, 1981) are retained. CR values, which depict the degree to which the construct indicators indicate the latent construct ranged from 0.850 to 0.927 which exceeded the recommended value of 0.7 (Hair et al., 2014). The AVE, which reflects the overall amount of variance in the indicators accounted for by the latent construct, were in range of 0.52 and 0.65 which exceeded the recommended value of 0.5 (Hair et al., 2014).

Table 1. Convergent validity of the reflective items in the measurement model

\begin{tabular}{|c|c|c|c|c|}
\hline Construct & Indicator & Loadings & CR & AVE \\
\hline & AIF1 & 0.786 & & \\
\cline { 2 - 3 } & & &
\end{tabular}


The Turkish Online Journal of Design, Art and Communication - TOJDAC

ISSN: 2146-5193, September 2018 Special Edition, p.824-831

\begin{tabular}{|c|c|c|c|c|}
\hline \multirow{4}{*}{ Access to Finance } & \multirow{3}{*}{$\begin{array}{l}\text { AIF2 } \\
\text { AIF3 }\end{array}$} & \multirow{3}{*}{$\begin{array}{l}0.821 \\
0.732\end{array}$} & \multirow[b]{4}{*}{0.863} & \multirow{4}{*}{0.61} \\
\hline & & & & \\
\hline & & & & \\
\hline & AIF4 & 0.785 & & \\
\hline \multirow{7}{*}{ Acceptance } & AUOFT1 & 0.719 & \multirow[b]{7}{*}{0.927} & \multirow[b]{7}{*}{0.65} \\
\hline & AUOFT2 & 0.766 & & \\
\hline & AUOFT3 & 0.819 & & \\
\hline & AUOFT4 & 0.835 & & \\
\hline & AUOFT5 & 0.838 & & \\
\hline & AUOFT6 & 0.786 & & \\
\hline & AUOFT7 & 0.854 & & \\
\hline \multirow{7}{*}{ Effort Expectancy } & EE1 & 0.766 & \multirow[b]{7}{*}{0.893} & \multirow[b]{7}{*}{0.54} \\
\hline & EE2 & 0.755 & & \\
\hline & EE3 & 0.662 & & \\
\hline & EE4 & 0.694 & & \\
\hline & EE5 & 0.705 & & \\
\hline & EE6 & 0.813 & & \\
\hline & EE7 & 0.762 & & \\
\hline \multirow{7}{*}{ Facilitating Condition } & $\mathrm{FC} 2$ & 0.752 & \multirow[b]{7}{*}{0.882} & \multirow[b]{7}{*}{0.52} \\
\hline & $\mathrm{FC} 3$ & 0.744 & & \\
\hline & FC4 & 0.708 & & \\
\hline & FC5 & 0.759 & & \\
\hline & FC6 & 0.732 & & \\
\hline & FC7 & 0.688 & & \\
\hline & FC8 & 0.647 & & \\
\hline \multirow{6}{*}{ Performance Expectancy } & PE1 & 0.780 & \multirow[b]{6}{*}{0.870} & \multirow[b]{6}{*}{0.53} \\
\hline & PE2 & 0.840 & & \\
\hline & PE3 & 0.757 & & \\
\hline & PE4 & 0.756 & & \\
\hline & PE6 & 0.558 & & \\
\hline & PE7 & 0.647 & & \\
\hline \multirow{3}{*}{ Social Influence } & SI1 & 0.724 & & \\
\hline & SI3 & 0.770 & & \\
\hline & SI4 & 0.755 & & \\
\hline
\end{tabular}




\begin{tabular}{|l|l|l|l|l|}
\hline SI5 & 0.726 & & \multirow{2}{*}{0.5} \\
\cline { 2 - 3 } & SI6 & 0.665 & 0.850 & 0.53 \\
\hline
\end{tabular}

\section{Discriminant Validity of Construct}

Next we proceed to test the discriminant validity. Table 2 indicates that all constructs exhibit sufficient or satisfactory discriminant validity (Türel \& Johnson, 2012), where the square root of AVE (diagonal) is larger than the correlations (off-diagonal) for all reflective constructs.

Table 2. Discriminant validity of construct

\begin{tabular}{|l|c|c|c|c|c|c|c|}
\hline & $\mathbf{1}$ & $\mathbf{2}$ & $\mathbf{3}$ & $\mathbf{4}$ & $\mathbf{5}$ & $\mathbf{6}$ & $\mathbf{7}$ \\
\hline 1. Access to Finance & 0.782 & & & & & & \\
\hline 2. Acceptance & 0.115 & 0.804 & & & & & \\
\hline 3. Effort Expectancy & 0.260 & 0.540 & 0.738 & & & & \\
\hline 4. Facilitating Condition & 0.254 & 0.481 & 0.599 & 0.719 & & & \\
\hline 5. Government Support & 0.212 & 0.399 & 0.383 & 0.277 & 0.735 & & \\
\hline 6. Performance Expectancy & 0.265 & 0.311 & 0.577 & 0.440 & 0.350 & 0.729 & \\
\hline 7. Social Influence & 0.240 & 0.512 & 0.625 & 0.645 & 0.253 & 0.474 & 0.729 \\
\hline
\end{tabular}

\section{Assessment Structural Model}

To assess the structural model involves evaluating $\mathrm{R}^{2}$, beta and the corresponding $\mathrm{t}$-values (Fornell \& Larcker, 1981). To obtain the t-values, a bootstrapping procedure with 5000 samples was applied. Predictive relevance $\left(\mathrm{Q}^{2}\right)$ and effect sizes $\left(\mathrm{f}^{2}\right)$ should also can be obtained and need to be report. The latent variables are Performance Expectancy $(\beta=-0.102, p>0.05, t<1.645)$, Effort Expectancy $(\beta=$ $0.214, p<0.05, t>1.645)$, Social Influence $(B=0.199, p<0.05, t>1.645)$, Facilitating Conditions $(B$ $=0.153, p<0.05, \mathrm{t}>1.645)$ and Access to Finance $(B=-0.045, \mathrm{p}>0.05, \mathrm{t}<1.645)$ as shown in Table 3.

Table 3. Assessment structural model

\begin{tabular}{|c|c|c|c|c|c|c|}
\hline Hypothesis & & Std. Beta & Std. Error & P-Value & t-Value & Decision \\
\hline H1 & PE-> Accept & -0.102 & 0.079 & 0.100 & 1.284 & Not Supported \\
\hline H2 & EE->Accept & 0.214 & 0.099 & $0.015^{* *}$ & $2.174^{* *}$ & Supported \\
\hline H3 & SI->Accept & 0.199 & 0.083 & $0.008^{* *}$ & $2.410^{* *}$ & Supported \\
\hline H4 & FC->Accept & 0.153 & 0.085 & $0.035^{* *}$ & $1.811^{* *}$ & Supported \\
\hline H5 & AIF->Accept & -0.045 & 0.079 & 0.284 & 0.571 & Not Supported \\
\hline
\end{tabular}

\section{CONCLUSION}

The latent variable proposed was hypothesized to be positively related to the acceptance towards sustainable farming technology. This study however found that two out of five latent variable that being hypothesized was not supported. The latent variables are Performance Expectancy $(\beta=-0.102, p$ $>0.05, \mathrm{t}<1.645)$ and Access to Finance $(\beta=-0.045, \mathrm{p}>0.05, \mathrm{t}<1.645)$ was not supported. However Effort Expectancy $(B=0.214, p<0.05, t>1.645)$, Social Influence $(B=0.199, p<0.05, t>1.645)$ and Facilitating Conditions $(B=0.153, \mathrm{p}<0.05, \mathrm{t}>645)$ were supported. The negative relationship between performance expectancy, access to finance and acceptance of sustainable farming technology may suggest that farmers rely on the customary way of farming. A study conducted by Türel and Johnson (2012) mentioned that performance expectancy does not affect the acceptance toward using a 
technology. It shows that effort expectancy, social influence and facilitating conditions positively influence farmers to accept sustainable farming technology. In other words, farmers accept sustainable farming technology for their farm when the technology will ease their work activities, other farmers using sustainable farming technology and they are being facilitated with support such as organizational and technical infrastructure support. The results answered the goal that is to distinguish the elements that urge farmers to acknowledge Sustainable farming technology.

\section{ACKNOWLEDGMENTS}

The authors would like to express their deepest appreciation to Universiti Teknikal Malaysia Melaka (UTeM) and Universiti Teknologi MARA (UiTM) Melaka for the support and motivation.

\section{REFERENCES}

Abdullah, N. H., Shamsuddin, A., Wahab, E., \& Hamid, N. A. (2012). Preliminary qualitative findings on technology adoption of Malaysian SMEs. In IEEE Colloquium Humanities, Science and Engineering, pp. 15-20.

Amoako-Gyampah, K. (2007). Perceived usefulness, user involvement and behavioral intention: An empirical study of ERP implementation. Computers in Human Behavior, 23(3), 1232-1248.

Bakar, K. A., Sam, M. F. M., Tahir, M. N. H., Rajiani, I., \& Muslan, N. (2011). Green technology compliance in Malaysia for sustainable business development. Journal of Global Management, 2(1), 55-65.

Bhatta, G. D., Doppler, W., \& Bahadur, K. B. (2009). Potentials of organic agriculture in Nepal. Journal of Agriculture and Environment, 10, 1-14.

Carter, L., Christian Shaupp, L., Hobbs, J., \& Campbell, R. (2011). The role of security and trust in the adoption of online tax filing. Transforming Government: People, Process and Policy, 5(4), 303-318.

Cook, A. J., \& Fairweather, J. R. (2003). New Zealand farmer and grower intentions to use gene technology: Results from a resurvey. AgBioForum, 6, 120-127.

Davis, F. D. (1989). Perceived usefulness, perceived ease of use, and user acceptance of information technology. MIS Quarterly, 13, 319-340.

De Graaff, J., Amsalu, A., Bodnar, F., Kessler, A., Posthumus, H., \& Tenge, A. (2008). Factors influencing adoption and continued use of long-term soil and water conservation measures in five developing countries. Applied Geography, 28(4), 271-280.

De Ponti, T., Rijk, B., \& Van Ittersum, M. K. (2012). The crop yield gap between organic and conventional agriculture. Agricultural Systems, 108, 1-9.

Doss, C. R. (2006). Analyzing technology adoption using microstudies: Limitations, challenges, and opportunities for improvement. Agricultural Economics, 34(3), 207-219.

Durkin, M., McGowan, P., \& Babb, C. (2013). Banking support for entrepreneurial new venturers: Toward greater mutual understanding. Journal of Small Business and Enterprise Development, 20(2), 420-433.

Economic Planning Unit (2010). 10th Malaysia Plan 2011-2015. Prime Minister's Department.

Fornell, C., \& Larcker, D. F. (1981). Evaluating structural equation models with unobservable variables and measurement error. Journal of Marketing Research, 18, 39-50.

Garcia-Yi, J. (2014). Organic coffee certification in Peru as an alternative development-oriented drug control policy. International Journal of Development Issues, 13(1), 72-92.

Hair Jr, J. F., Black, W. C., Babin, B. J., \& Anderson, R. E. (2010). Multivariate data analysis: A global perspective. Pearson Education.

Hair, J. F., Gabriel, M., \& Patel, V. (2014). AMOS covariance-based structural equation modeling (CB-SEM): Guidelines on its application as a marketing research tool. Brazilian Journal of Marketing, 3, 44-55.

Hu, Q. H., Zhang, L. X., \& Wang, C. B. (2012). Energy-based analysis of two chicken farming systems: A perception of organic production model in China. Procedia Environmental Sciences, 13, 445-454.

Iacovou, C. L., Benbasat, I., \& Dexter, A. S. (1995). Electronic data interchange and small organizations: Adoption and impact of technology. MIS Quarterly, 19, 465-485.

Kathiresan, R. M. (2007). Integration of elements of a farming system for sustainable weed and pest management in the tropics. Crop Protection, 26(3), 424-429. 
Kersting, S., \& Wollni, M. (2012). New institutional arrangements and standard adoption: Evidence from small-scale fruit and vegetable farmers in Thailand. Food Policy, 37(4), 452-462.

Klöckner, C. A., \& Ohms, S. (2009). The importance of personal norms for purchasing organic milk. British Food Journal, 111(11), 1173-1187.

Kumar, M., Abdul Talib, S., \& Ramayah, T. (2013). Business research methods. Oxford Fajar Sdn. Bhd.

Lankton, N. K., McKnight, D. H., \& Tripp, J. (2015). Technology, humanness, and trust: Rethinking trust in technology. Journal of the Association for Information Systems, 16(10), 880-918.

Maffei, D. F., de Arruda Silveira, N. F., \& Catanozi, M. D. P. L. M. (2013). Microbiological quality of organic and conventional vegetables sold in Brazil. Food Control, 29(1), 226-230.

Mohamed, Z., \& Shamsudin, M. N. (2011). Malaysian consumer's perceptive towards purchasing organically produce vegetable. In 2nd International Conference on Business and Economic Research.

Noltze, M., Schwarze, S., \& Qaim, M. (2012). Understanding the adoption of system technologies in smallholder agriculture: The system of rice intensification (SRI) in Timor Leste. Agricultural Systems, 108, 64-73.

Pattanapant, A., \& Shivakoti, G. P. (2009). Opportunities and constraints of organic agriculture in Chiang Mai province, Thailand. Asia-Pacific Development Journal, 16(1), 115.

Oleskowicz-Popiel, P., Kádár, Z., Heiske, S., Klein-Marcuschamer, D., Simmons, B. A., Blanch, H. W., \& Schmidt, J. E. (2012). Co-production of ethanol, biogas, protein fodder and natural fertilizer in organic farming-Evaluation of a concept for a farm-scale biorefinery. Bioresource Technology, 104, 440-446.

Olson, E. G. (2008). Creating an enterprise-level "green" strategy. Journal of Business Strategy, 29(2), 22-30.

Patil, S., Reidsma, P., Shah, P., Purushothaman, S., \& Wolf, J. (2014). Comparing conventional and organic agriculture in Karnataka, India: Where and when can organic farming be sustainable? Land Use Policy, 37, 40-51.

Ramayah, T., Yeap, J. A., \& Ignatius, J. (2013). An empirical inquiry on knowledge sharing among academicians in higher learning institutions. Minerva, 51(2), 131-154.

Santos, V. B., Araújo, A. S., Leite, L. F., Nunes, L. A., \& Melo, W. J. (2012). Soil microbial biomass and organic matter fractions during transition from conventional to organic farming systems. Geoderma, 170, 227-231.

Sekaran, U., \& Bougie, R. (2016). Research methods for business: A skill building approach. John Wiley and Sons.

Tey, Y. S., Li, E., Bruwer, J., Abdullah, A. M., Cummins, J., Radam, A., Ismail MM, \& Darham, S. (2012). Adoption rate of sustainable agricultural practices: A focus on Malaysias vegetable sector for research implications. African Journal of Agricultural Research, 7(19), 2901-2909.

Treven, S. (2003). International training: The training of managers for assignment abroad. Education+ Training, 45(8/9), 550-557.

Tuomisto, H. L., Hodge, I. D., Riordan, P., \& Macdonald, D. W. (2012). Exploring a safe operating approach to weighting in life cycle impact assessment-A case study of organic, conventional and integrated farming systems. Journal of Cleaner Production, 37, 147-153.

Türel, Y. K., \& Johnson, T. E. (2012). Teachers' belief and use of interactive whiteboards for teaching and learning. Educational Technology and Society, 15(1), 381-394.

Venkatesh, V., \& Davis, F. D. (2000). A theoretical extension of the technology acceptance model: Four longitudinal field studies. Management Science, 46(2), 186-204.

Venkatesh, V., Morris, M. G., Davis, G. B., \& Davis, F. D. (2003). User acceptance of information technology: Toward a unified view. MIS Quarterly, 27, 425-478. 